\title{
Siasat Manipulatif Partai Politik
}

\section{Political Party Manipulative Strategy}

\author{
Bimantara Ilham Dewanto \\ Departemen Antropologi, Fakultas Ilmu Sosial dan Politik, Universitas Airlangga \\ Alamat: Jalan Dharmawangsa Dalam Selatan, Surabaya, Indonesia \\ Email: bimantarailham94@gmail.com
}

\begin{abstract}
Abstrak
Siasat politik partai membentuk sebuah budaya yang mempengaruhi perilaku kader-kader PDIP Kota Surabaya dalam mencapai tujuan politiknya. Focus studi ini pada fenomena siasat manipulatif partai politik dalam praktik politik mikro untuk mendapatkan elektabilitas di Kota Surabaya. Penelitian ini menggunakan metode etnografi. Wawancara mendalam digunakan kepada informan dari partai. Hasil penelitian menunjukkan bahwa budaya kaderisasi partai dimulai dari sosialisasi rekrutmen anggota, ketentuan anggota baru, tingkatan dan fungsi bidang kaderisasi, jenjang kaderisasi partai, penanaman ideologi partai, dan mekanisme pemilihan kader menjadi calon partai. Dinamika yang dialami kader partai politik adalah adanya perebutan kekuasaan internal partai, kurangnya pengetahuan ilmu politik, dan harapan masyarakat yang terlampau tinggi terhadap kader terpilih. Siasat manipulatif/politik mikro partai politik untuk pemenangan saat mengikuti Pemilihan Anggota Legislatif (DPRD) dan Pemilihan Walikota di Kota Surabaya adalah: 1) Penentuan calon bukan dari kader partai; 2) Kegiatan sosial menjelang pemilu; 3) Memanfaatkan jabatan publik untuk bekerja optimal; 4) Membangun citra partai untuk mengangkat citra kader; dan 5) Melibatkan orang lain untuk mendulang suara.
\end{abstract}

Kata kunci: siasat manipulatif, partai politik, kader partai, bukan kader partai, budaya kaderisasi

\begin{abstract}
The party's political tactics form a culture that influences the behavior of PDIP Surabaya City cadres in achieving their political goals. The focus of this study is on the phenomenon of manipulative tactics of political parties in the practice of micropolitics to gain electability in the city of Surabaya. This research used the ethnographic method. In-depth interviews were used with party informants. The results showed that the party regeneration culture started from the socialization of member recruitment, provisions for new members, levels and functions of the field of regeneration, the level of party regeneration, instilling party ideology, and the mechanism for selecting cadres to become party candidates. The dynamics experienced by political party cadres are internal party power struggles, lack of knowledge of political science, and public expectations that are too high for elected cadres. The manipulative/micro-political tactics of political parties to win when participating in the Election of Legislative Members (DPRD) and the Election of Mayors in the City of Surabaya are: 1) Determination of candidates not from party cadres; 2) Social activities ahead of the election; 3) Utilizing public office to work optimally; 4) Building the party's image to raise the image of cadres; and 5) Involving other people to gain votes.
\end{abstract}

Keywords: manipulative tactics, political parties, parties cadres, not parties cadres, regeneration culture

Biokultur, 2021, 10 (2): 97-106. DOI: http://dx.doi.org/10.20473/bk.v10i2.31714

Article History:

Received November 27, 2021; Accepted November 30, 2021; Published Online December 22, 2021. 


\section{Pendahuluan}

Studi ini bertujuan mengungkap bagaimana siasat yang dilakukan partai politik untuk meraih elektabilitas tinggi ketika pemilihan legislatif. Berbagai siasat dilakukan partai politik di Indonesia untuk memenangkan pemilihan legislatif. Partai politik ini beranggotakan bermacam individu dari berbagai latar belakang sosial budaya dan ekonomi. Pimpinan dan anggota partai politik sebagai manusia merupakan makhluk politis karena mereka tidak dapat hidup dan berkembang apabila hanya mengandalkan diri dan kemampuannya, manusia dalam hidup perlu bersosialisasi, bermasyarakat dan bernegara (Maran 2007:7). Oleh karenanya manusia sebagai makhluk politis, maka kehidupan yang dijalani oleh manusia tidak luput dari pengaruh kondisi lingkungan sosial, masyarakat, organisasi, berbangsa dan bernegara.

Organisasi menurut Robbins dan Judge (2008:5) adalah sebuah unit sosial yang dikoordinasikan secara sadar, terdiri atas dua orang atau lebih dan yang relatif terus-menerus guna mencapai satu atau serangkaian tujuan bersama. Partai politik merupakan sebuah organisasi yang dikelola oleh para anggotanya secara terorganisir, mereka memiliki persamaan cita-cita, orientasi, dan nilai-nilai (Budiardjo, 2008:404). Pengertian Partai politik telah dijelaskan dalam Undang-Undang Nomor 2 Tahun 2008 Pasal 1 ayat 1 tentang Partai Politik, bahwa partai politik adalah organisasi yang bersifat nasional dan dibentuk oleh sekelompok warga negara Indonesia secara sukarela atas dasar kesamaan kehendak dan cita-cita untuk memperjuangkan dan membela kepentingan politik anggota, masyarakat, bangsa dan negara, serta memelihara keutuhan Negara Kesatuan Republik Indonesia berdasarkan Pancasila dan Undang-Undang Dasar Negara Republik Indonesia Tahun 1945.

Bagi masyarakat, partai politik sudah tidak asing lagi. Politik merupakan upaya dalam membuat peraturan-peraturan yang oleh mayoritas masyarakat dapat diterima dengan baik, sehingga dapat menjadikan masyarakat menuju kepada kehidupan bersama yang lebih baik (Budiardjo 2008:15).

Partai politik sebagai sebuah organisasi memiliki nilai-nilai berupa budaya organisasi yang menginternalisasi dalam diri anggotanya. Budaya organisasi menurut Koentjaraningrat (2002) ialah nilai yang hidup dalam alam fikiran sebagian besar warga masyarakat mengenai hal-hal yang mereka anggap amat mulia. Pada praktiknya, salah satu wujud budaya organisasi di sebuah partai politik ialah model perekrutan dan pengkaderan anggota yang memiliki perbedaan jika dibandingkan dengan partai politik lainnya, perbedaan tersebut tergantung dari kepentingan, visi misi dan tujuan masing-masing partai politik. Perekrutan dan pengkaderan anggota oleh partai politik berarti menjalankan fungsi penting bagi keberlangsungan dan kesinambungan partai politik. Undang-Undang No 2 Tahun 2008 Pasal 11 ayat 1 tentang rekrutmen politik menjelaskan bahwa partai politik merupakan wadah untuk melakukan rekrutmen politik sebagai proses dalam mengisi jabatan-jabatan politik melalui mekanisme pemilihan umum (demokrasi) dengan memperhatikan keadilan dan kesetaraan gender. Indikator yang dapat dijadikan pedoman untuk menilai sejauhmana efektivitas partai politik sebagai sarana rekrutmen politik berjalan secara efektif ialah berdasarkan besar/kecilnya peran partai politik dalam memenangkan pemilihan untuk dalam pengisian jabatan politik.

Kaderisasi di partai politik bertujuan untuk menciptakan pemimpin-pemimpin berkualitas yang dapat meneruskan perjuangan, ideologi, dan visi dari organisasi partai (Cholisin, 2004: 161). Cara yang digunakan dalam memberikan pendidikan menurut Winataputra dan Budimansyah (2007: 188) berdasarkan civic skills yang terdiri atas ketrampilan partisipasi/participation skills dan ketrampilan intelektual/ intelectual skills yaitu ketrampilan penting yang harus dikuasai 
supaya menjadi kader yang bertanggung jawab, berwawasan luas, dan efektif. Selanjutnya pengertian kaderisasi informal adalah segala aktifitas diluar pengkaderan formal yang dapat menunjang proses kaderisasi. Klasifikasi pengkaderan informal meliputi: aktivitas kepanitian, pimpinan kelembagaan, penugasan-penugasan dan sejenisnya.

Menurut Harjanto (2011), partai politik merupakan sarana rekrut pemimpin lokal sampai nasional melalui kaderisasi kepemimpinan. Sayangnya partai politik di Indonesia lebih menonjolkan politik kekerabatan, tokoh luar bukan kader asli, tokoh non-partai politik untuk meraih kemenangan pada pilkada/pemilihan kepala daerah.

Penelitian Panantang (2012), menunjukkan perekrutan dan dua model kaderisasi PDIP DPC Kota Kediri, yaitu 1) inisiatif masyarakat sendiri dan upaya aktif kader partai mengajak anggota masyarakat; 2) gerakan kaderisasi dan kaderisasi yang sistem kelas. Permana (2015) meneliti pola kaderisasi kepemimpinan di DPC PDI Perjuangan Kabupaten Nganjuk. Simpulannya menunjukkan bahwa tahapan rekruitmen, penyeleksian pendidikan kader sesuai Anggaran Rumah Tangga (ART) Partai, yaitu mekanisme penentuan calon anggota dan anggota melalui musyawarah untuk mufakat. Begitu pula dalam penentuan pemimpin partai politik di DPC PDI Perjuangan Kabupaten Nganjuk. Kaderisasi kepemimpinan dilakukan dengan mentransfer pengetahuan, keterampilan dan keahlian. Kaderisasi tersebut nantinya digunakan dalam meneruskan tujuan dan perjuangan partai. Kaderisasi kepemimpinan dalam organisasi berguna untuk mengatur sistem dalam partai. Sistem kaderisasi kepemimpinan di DPC PDI Perjuangan terdiri dari proses rekruitmen, seleksi kader dan pendidikan kader merupakan proses berkesinambungan yang dilakukan partai untuk mempersiapkan calon pemimpin internal partai yag nanti akan menjadi calon pejabat publik. Proses rekruitmen dan seleksi yang dilakukan dengan musyawarah mufakat akan menambah pemahaman anggota PDI Perjuangan tentang Pancasila terutama sila ke-4 yang berbunyi permusyawaratan yang dipimpin oleh hikmat kebijaksanaan bagi seluruh rakyat Indonesia. Pemilihan anggota kader partai dan calon pemimpin apabila tidak ditemukan kemufakatan, dilakukan dengan voting atau pengambilan suara terbanyak akan meningkatkan kejujuran dan keterbukaan tiap anggota dan kader partai terhadap aspirasi mereka, sehingga pemilihan calon pemimpin berjalan lebih demokratis. Pelaksanaan dalam hal ini merupakan proses atau usaha-usaha untuk mempersiapkan seorang kader secara terencana maupun tidak terencana untuk menjadi pemimpin internal partai yang nantinya akan menduduki sebagai calon pajabat publik .

Berdasarkan observasi peneliti menunjukkan bahwa partai besar pemenang legislatif di Kota Surabaya, memiliki berbagai siasat untuk dapat keluar sebagai pemenang lagi dalam pemilihan legislatif dan eksekutif. Masalah yang dikaji lebih mendalam adalah bagaimana siasat partai politik dalam memenangkan pemilihan legislatif dan eksekutif di Kota Surabaya?

\section{Metode}

Tipe penelitian ini kualitatif dengan pendekatan dan metode etnografi. Penelitian ini berfokus mengkaji budaya kaderisasi mulai dari rekrutmen hingga penentuan kader partai yang akan diusung sebagai calon dalam pemilihan legislatif dan pemilihan walikota di Kota Surabaya. Selanjutnya mendeskripsikan dinamika yang dihadapi dan siasat manipulatif yang dikembangkan dalam upaya memperoleh dukungan dari masyarakat dalam pemilihan legislatif dan pemilihan eksekutif/walikota di Kota Surabaya. 
Penelitian ini berlokasi di Kantor Dewan Pimpinan Cabang (DPC) salah satu Partai Politik di Kota Surabaya. Pemilihan lokasi penelitian berdasarkan pertimbangan bahwa Kantor DPC partai politik tersebut merupakan pusat aktivitas kaderisasi partai. Teknik pemilihan informan yang dipilih oleh peneliti sebanyak lima informan antara lain: 1). Informan - I ialah pengurus partai dan anggota dewan; 2). Informan - II ialah kader partai; 3). Informan - III ialah anggota dewan; 4). Informan - IV ialah pengurus harian dan kader; serta 5). Informan - V ialah pihak luar yang mengetahui budaya kaderisasi partai. Teknik pengumpulan data yang digunakan dalam penelitian ini adalah observasi tentang aktivitas pelatihan dan aktivitas anggota partai. Wawancara mendalam kepada informan dengan pedoman wawancara.

\section{Hasil dan Pembahasan}

Dari tingkatan kader di PDIP, informan menjelaskan bahwa salah satu fungsi penting kelestarian dan keberlangsungan sebuah partai politik ialah perekrutan kader partai politik. Bagi anggota baru yang direkrut oleh partai partai, selanjutnya diikutkan pada kegiatan kaderisasi partai yang berguna untuk kepentingan rekrutmen pengurus partai dan kepentingan penjaringan calon peserta pemilu yang diusung partai untuk pemilihan anggota legislative, kepala dan wakil daerah. Dalam mencari anggota yang akan dikader, PDIP menggunakan anak ranting dan PAC/Pengurus Anak Cabang untuk menjaring kader-kadernya. Kader ini nantinya diikutkan dalam acara kaderisasi anak ranting dan PAC menempatkan orang di tiap pelosok, untuk mencari bibit atau calon yang nantinya menjadi penerus tongkat estafet organisasi partai.

Ditingkat cabang atau DPC dalam serangkaian kaderisasinya diisi oleh perwakilan oleh pimpinan cabang, wakabid/wakil kepala bidang kaderisasi, dan perwakilan oleh DPP/Dewan Pengurus Pusat. Acara ini biasanya dilakukan di aula hotel di wilayah Surabaya. Acara kaderisasi PDIP tidak jauh beda dengan acara formal pada umumnya. Dibuka oleh moderator dengan menyanyikan lagu Indonesia Raya. Setelah itu doa bersama, sambutan ketua DPC, ketua DPP atau perwakilanya, dilanjut perwakilan dari PAC. Lalu kegiatan ramah tamah, makan bersama. Sambutan perwakilan DPP untuk wilayah kota Surabaya ialah Ketua Umum dan pimpinan dari DPC, yaitu bisa dari ketua partai atau wakabid kaderisasi dan organisasi. Acara kaderisasi ini bertujuan untuk memperkuat hubungan antar elemen partai, karena keberhasilan dalam menjalankan kegiatan partai tidak hanya mengandalkan beberapa tokoh saja melainkan juga hasil kerja keras para kader PDIP. Acara kaderisasi ini dilaksanakan supaya peserta kaderisasi tidak merasa jenuh atau bosan.

Rekrutmen anggota baru pelaksanaannya dimulai dengan pemberian sosialisasi partai kepada masyarakat untuk menginformasikan pembukaan pendaftaran untuk menjadi anggota baru partai. Informasi yang disampaikan saat rekrutmen anggota ialah berupa apa saja kegiatan yang ada di PDIP. Pemberitahuan ini diinformasikan melalui media cetak, elektronik dan website. Bentuk lain sosialisasi yang dilaksanakan partai ialah dengan cara menunjukkan kinerja partai pada masyarakat. Apabila kinerja partai baik di mata masyarakat, maka tidak menutup kemungkinan masyarakat akan masuk menjadi anggota PDIP

Menurut informan:

"DPC PDI Perjuangan Kota Surabaya menggunakan cara yang lebih bersifat ajakan persuasif dalam rekrutmen anggota baru, bukan cuci otak, pemberian uang ataupun paksaan. Partai ini mengedepankan ideologi dan program partai yang berusaha untuk menunjukkan konsistensi ideologi dengan program yang dibuat dan dijalankan, jadi semuanya terserah pada masyarakat bersedia menilai apakah layak menjadi partainya atau tidak." 
Selanjutnya dikatakan informan bahwa

"Dalam rekrutmen anggota baru, partai tidak pilih-pilih. Demikian juga dalam merekrut pengurus, karena dari kalangan manapun bisa menjadi anggota hingga pengurus partai seperti tukang becak ataupun kuli. Calon anggota partai harus melalui masa pembinaan. Masa pembinaan berfungsi membentuk kader dengan memunculkan kualitas."

Masa pembinaan ini dilakukan selama enam bulan yang mana selama selang waktu itu, pengurus partai terus melakukan pemantauan aktivitas calon anggota baru. Dalam kurun waktu enam bulan tersebut, tiap satu orang anggota diberi kewajiban minimal dapat mengajak satu orang anggota baru untuk bergabung. Calon yang sudah mendaftar memperoleh materi terkait seluk beluk PDIP, AD/ART (Anggaran Dasar/Anggaran Rumah Tangga) dan berkesempatan berdialog secara langsung dengan kader atau pengurus partai di jenjang struktural.

Seluruh elemen partai ikut terlibat dan bertanggung jawab dalam rekrutmen anggota baru. Mereka diberikan pembekalan sebelumnya tentang pelaksanaan perekrutan anggota baru dalam forum konsolidasi partai. Kaderisasi di partai terdapat bidang yang menanganinya, yaitu Badiklat/Badan Pendidikan Latihan yang ada di pusat, Badiklatda di tingkat daerah dan Badiklatcab yang ada di tingkat cabang. Adapun masing-masing bidang kaderisasi mempunyai peran sesuai tingkat wilayahnya, antara lain: pada kaderisasi tingkat pratama: materi yang disampaikan ialah mengenai bagaimana ansos/analisis sosial kader, lalu untuk tingkat madya mengenai bagaimana seorang kader dalam memanajemen isu dan sebagainya, selanjutnya kaderisasi tingkat utama menyangkut bagaimana kader memahami kondisi geopolitik, geostrategi lalu isu-isu nasional, bagaimana determinasi isu, dan memunculkan isu.

Dalam proses seleksi kader partai di PDI Perjuangan terdapat tiga jenjang yaitu: (1) Jejang pertama untuk Kader Pratama, kaderisasi jenjang pertama adalah kaderisasi yang dilakukan oleh partai di tingkat paling bawah, yaitu DPC. Kaderisasi ini dilakukan oleh partai di tingkat Daerah, Desa atau Kelurahan dan Kabupaten atau Kota. Kaderisasi ini merupakan usaha partai dalam rangka memperkuat dan memperluas basis massa di Daerah. Dimana kaderisasi jenjang pertama ini berguna untuk mempersiapkan kader untuk mengisi jabatan-jabatan publik di tingkat paling rendah yaitu jabatan di tingkat Kabupaten atau Kota; (2) Jenjang kedua untuk Kader Madya, Kaderisasi jenjang kedua, adalah kaderisasi yang dilakukan oleh partai di tingkat menengah. Kaderisasi ini dilakukan oleh partai di tingkat provinsi. Kaderisasi ini bersifat fungsional yaitu kaderisasi berdasarkan atas pengelompokan terhadap kelompok strategis (pemuda, mahasiswa, pengusaha, dan lain-lain).

Kaderisasi di jejang kedua ini berfungsi untuk mempersiapkan kader yang akan mengisi jabatan-jabatan publik di tingkat provinsi baik sebagai calon legislatif tingkat Provinsi dan Gubernur; dan (3) Jenjang ketiga untuk Kader Utama, kaderisasi jenjang utama atau jenjang ketiga merupakan proses kaderisasi yang dilakukan di tingkat paling atas yaitu DPP. Kaderisasi jenjang ketiga diselenggarakan oleh partai ditujukan untuk kader yang akan diusung oleh partai dalam pemilihan umum untuk menduduki jabatan politik (eksekutif dan legislatif) dalam upaya mencapai dan mewujudkan tujuan partai.

Kaderisasi yang berlaku di partai mengutamakan adanya regenerasi dan pengkaderan dari tingkat bawah. Partai mempunyai pengurus mulai dari tingkat RW hingga pusat. Pada tingkat RW terdapat pengurus yang terdiri dari 1 orang ketua, 2 orang wakil, 1 orang sekretaris, dan 1 orang bendahara. Kemudian kepengurusan tingkat kelurahan terdapat 1 orang ketua, 2 orang wakil, 1 orang sekretaris, dan 1 orang bendahara. Tingkat kecamatan terdapat pengurus anak cabang, Dewan Perwakilan Cabang (DPC), Dewan Pimpinan Daerah (DPD), Dewan Pimpinan Pusat (DPP). Pengkaderan berjenjang yang berlaku di partai mulai dari tingkat RW hingga 
pusat merupakan kelebihan partai dalam regenerasi partai, model kaderisasi seperti ini belum tentu dilakukan oleh partai lain.

Kaderisasi PDIP terbagi menjadi tiga tahapan, yaitu: tingkat pratama yang diadakan oleh Dewan Pimpinan Cabang (DPC), tingkat madya yang mengadakan adalah Dewan Pimpinan Daerah (DPD) dengan pesertanya adalah kiriman dari DPC dan DPD, lalu yang terakhir adalah tingkat utama dilakukan oleh Dewan Pimpinan Pusat. Di samping adanya kaderisasi dari tiga tingkatan tersebut, partai juga mengadakan pelatihan dan bimbingan teknis untuk para kader di tingkat daerah untuk pembekalan tentang bagaimana pengelolaan anggaran sebagai anggota DPR, sikap politik, tugas pokok wewenang, bagaimana menangani anti korupsi lalu diklat juru bicara kader, diklat untuk guratle, diklat untuk saksi dan sebagainya. Hal tersebut dilaksanakan oleh partai karena tidak ingin menjadi partai pemenang saja, melainkan juga menjadi partai yang bisa menata dan juga bisa mempertahankan.

Dalam budaya kaderisasi partai, para kader harus memulai pada tingkat pratama terlebih dahulu kemudian melanjutkan ke tingkat madya dan di tingkat terakhir adalah tingkat utama. Para kader harus melalui tingkatan kaderisasi secara berurutan karena materi yang disampaikan pada tiap tingkatan juga berbeda, berkelanjutan, dan berhubungan. Sudah ada regulasi di internal partai untuk regenerasi kepemimpinan yang prosesnya dimulai dari bawah. Proses regenerasi Partai yang diawali dari akar sampai rumput itu hanya dimiliki oleh PDIP. Di partai lainnya tidak ada system seperti yang dipakai di yang dipakai di partai PDIP. Partai ini memiliki struktur dari tingkat paling bawah yaitu anak ranting hingga paling atas pengurus pusat. Pengambilan keputusan dilakukan dari tingkat terbawah hingga dibawa ke forum tertinggi, Kongres. Penanamkan ideologi dan perjuangan partai yang dilakukan oleh PDI Perjuangan kepada seluruh tatanan lapisan masyarakat secara kuat dan mengakar tidak bisa dilepaskan dari keunggulannya dalam membangun jaringan mulai dari strukturan terbawah.

PDI Perjuangan dapat menarik simpati masyarakat dengan mudah untuk ikut bergabung ke partai sebagai pendukung merupakan buah dari hasil sistem yang diterpakan PDI Perjuangan. Cara yang dilakukan oleh PDIP untuk mencari dukungan masyarakat bermula dari tingkat Desa, dengan mencari kader potensial dan tokoh berpengaruh. Kader yang memiliki kualitas diberikan tempat yang strategis di dalam kepemimpinan desa, sementara tokoh tersebut diberikan penawaran untuk terlibat menjadi anggota partai. Ideologi partai adalah marhaenisme yaitu partai yang peduli dengan masyarakat kecil "wong cilik". Ideologi harus senantiasa ditanamkan pada semua elemen partai PDI Perjuangan. Semua elemen partai harus mengerti dan memahami ideologi yang dianut. Pada sekolah partai yang dibagi menjadi beberapa tahapan tersebut dalam pemberian materi sudah terdapat silabusnya di Dewan Pimpinan Pusat (DPP).

Untuk menentukan kader yang akan diusung menjadi calon legislatif dan eksekutif ialah melalui beberapa tahap, salah satunya berdasarkan kriteria penilaian poin dengan meninjau pernah jadi pengurus apa, lalu juga dilihat dari tingkat kemampuannya terkait finansial. Selain itu, terpilih tidaknya kader menjadi calon juga ditinjau dari kuota yang diberikan yaitu sebanyak 10 orang, dari kuota tersebut terdiri dari kuota untuk kecamatan, DPC, dan kuota perempuan. Apabila pada suatu dapil dari semua unsur PAC dan DPC harus ada perempuannya supaya bisa lolos. Pemilihan kader bisa dimulai dari lingkup PAC hingga anak ranting. Apabila di lingkup PAC misalnya ketuanya yang dicalonkan tidak mumpuni maka bisa juga mengambil kader dari kecamatan entah sekretaris juga diperbolehkan. Jadi pada suatu dapil harus bisa memenuhi persyaratan pemenuhan kuota tersebut. 
Pemilihan kader diusahakan dari partai sendiri yang mana pemilihannya juga tidak sembarangan yang dipilih. Terdapat isu yang menyatakan bahwa apabila calon ingin mendapatkan rekom harus memberikan uang sekian. Itu semua merupakan ulah oknum supaya namanya bisa muncul. Proses pemilihan di partai benar-benar murni dipilih oleh rakyat jadi tidak ada suap menyuap. Namun menurut informan lain bahwa "sudah menjadi rahasia umum, bahwa program partai dimasukkan dalam program yang dilaksanakan oleh Pemerintah Kota Surabaya. Jika ada kegiatan Pemkot Surabaya sering ada pengibaran bendera PDIP”. Masyarakat menyaksikan kondisi ini.

Salah satu dinamika yang dialami selama pengkaderan ialah adanya pertarungan untuk meraih posisi dalam internal partai. Pada tingkat kepengurusan RT juga ada pemilihan anak ranting. Semua itu tergantung dari masing-masing individunya, untuk itu perlu dilakukan penataan yang benar sampai anak cabang PAC. Dalam budaya kaderisasi sendiri terdapat pembentukan kubu-kubu, selalu ada pertarungan seperti pada pemilihan calon legislatif beberapa bulan lalu. Pengurus tidak ada yang ikut mencalonkan diri pada pilihan calon legislatif sehingga mereka cenderung membentuk blok-blok berdasarkan calon yang didukungnya. Kubu-kubu ini terus berjalan jadi seorang yang sudah masuk kubu A apabila berkumpul dengan kubu B akan terancam dikeluarkan dari kubu A. Dinamika lainnya ialah banyaknya penjegalan oleh lawan politik. Lawan politik berupaya untuk menyingkirkan bahkan selama menjalani masa pencalonan.

Tidak hanya berupa persaingan dan penjegalan, dinamika lain yang dialami ialah kesulitan dalam memahami ilmu politik tidak sejak awal. Ketika pemahaman tentang ilmu politik kurang, maka yang dialami adalah stress dan bingung dalam menjalankan tugas, karena dalam setiap permasalahan yang dibahas dalam rapat tergantung pada komisi dan dinas yang bersangkutan. Jadi memahami ilmu politik sejak awal memang penting supaya sebagai kader tidak dibujuk atau dibodohi oleh pihak lain. Pembelajaran sejak awal bisa dilakukan dengan mengikuti berita-berita, dan sharing dengan ahli politik.

Dinamika lain yang juga dialami oleh kader ialah adanya pemikiran yang salah dari masyarakat bahwa calon adalah superman. Superman yang bisa menyelesaikan semua masalah. Padahal selesai tidaknya suatu masalah tergantung dari kemampuan dan setiap masalah mempunyai jalur penyelesaian masing-masing.

Meskipun kader telah menjelaskan keterbatasan tersebut, masyarakat masih belum bisa memahami sehingga mengakibatkan masyarakat kurang memberikan apresiasi atas kinerja yang telah dilakukan. Seharusnya timbul kesadaran dalam diri masyarakat bahwa tidak semua masalah bisa terselesaikan, semua itu tergantung dari kemampuan di bidang masing-masing.

Setiap kader PDIP yang mencalonkan diri untuk ikut dalam pemilihan anggota legislatif (DPRD) atau pemilihan walikota Surabaya tentu memiliki strategi berupa siasat untuk memperoleh suara mayoritas supaya terpilih menjadi anggota legislatif (DPRD) atau Walikota di Kota Surabaya. Dalam persaingan memenangkan pemilu legislatif dan walikota di Surabaya, para calon yang diusung oleh masing-masing partai politik menggunakan siasat manipulatif dalam mencapai tujuannya.

Bailey (1971), usaha tiap individu dalam permainan politik untuk mempengaruhi individuindividu lain melalui siasat manipulative/politik mikro. Politik mikro/siasat manipulatif yang diterapkan oleh kader PDIP Kota Surabaya, sesuai dengan pemikiran Bailey. Penentuan calon yang diusung oleh partai dalam pemilihan anggota legislatif ini berawal dari pemenuhan kuota 
calon perempuan oleh partai saat itu masih kurang, jadi berdasarkan rekomendasi dari DPP maka calon diusung menjadi calon dalam pemilihan legislatif Kota Surabaya.

Dalam penentuan calon yang diusung partai pada pemilihan umum legislatif dan eksekutif di Kota Surabaya, kewenangan DPC hanya sebatas mengusulkan nama dari kader partai, namun penentuan calon tergantung dari keputusan Dewan Pimpinan Pusat (DPP) partai. Calon yang diusung pada akhirnya tidak menutup kemungkinan berasal dari non kader partai, seperti kasus Risma yang mantan PNS dan bukan kader PDIP.

Strategi pemenangan calon dalam pemilihan anggota legislatif (DPRD) dan walikota oleh DPC PDIP Kota Surabaya ialah menyelenggarakan "kegiatan sosial" pada masa menjelang pemilu untuk menarik simpati masyarakat sehingga memperoleh dukungan suara. Sebagaimana penelitian Pattiasina (2015) yang menyebutkan bahwa strategi yang menjadi pilihan utama untuk dilaksanakan oleh setiap kader ialah strategi untuk pendekatan diri terhadap masyarakat pemilih. Seorang kader harus mampu memacu dirinya untuk dapat meningkatkan akseptabilitas dirinya dengan cara mendekatkan diri kepada masyarakat. Usaha-usaha pendekatan kepada masyarakat pemilih harus menjadi catatan penting dalam rangka mendulang perolehan suara partai politik. Oleh karenanya perayaan hari besar keagamaan, rapat RT, dan arisan warga sebagai bentuk kegiatan kemasyarakatan perlu diberikan perhatian khusus. Alasan apapun untuk kegiatan-kegiatan sebagai mana contoh di atas, dapat dianggap sebagai perbuatan mencuri start kampanye oleh calon untuk mendekati masyarakat pemilih (konstituen). Tersamarnya motif komunikasi kader pada kegiatan-kegiatan kemasyarakatan dapat mempengaruhi percepatan terciptanya sikap masyarakat terhadap profil, kompetensi dan peranannya di masyarakat. Aktivitas dan materi komunikasinya tidak bersifat mengada-ada dan dadakan, karena berisi kegiatan dan materi komunikasi yang dekat dengan persoalan dan kebutuhan masyarakat.

Salah satu tokoh di luar partai yang sukses dicalonkan oleh partai adalah Risma mantan kepala Bappeko Pemerintah Kota Surabaya sebagai calon Walikota Surabaya. Selama menjabat Walikota, Risma diangggap sebagian masyarakat kerja baik dan peduli terhadap kepentingan masyarakat meskipun tetap mengutamakan kepentingan partai pengusungnya. Siasat manipulative dilakukan Risma yang masih PNS dan PDIP sebagai partai pengusung budaya kerja partai.

Partai tidak menyediakan tim khusus untuk pemenangan calon saat pemilu, untuk itu pembentukan tim sukses diupayakan sendiri oleh calon. Dalam pembentukan tim sukses bagi calon yang bukan kader dan tidak memiliki basis pendukung yang banyak tentu akan mengalami kesulitan bersaing dengan calon lain. Namun melalui siasat manipulatif berupa pelibatan pihak lain, dengan memberi bantuan tertentu pada wilayah RW, yang sudah menjadi rahasia umum ada pendukung PDIP untuk mendulang suara. Siasat manipulative ini juga dilakukan partai lain sebagai partai pemenang pemilihan legislatif.

Siasat manipulatif ini telah terbukti berhasil dilakukan oleh salah satu calon partai yang kini duduk sebagai anggota dewan Kota Surabaya ketika pemilihan legislatif. Dalam menjalankan siasat manipulatif, pelibatan orang lain dalam upaya mendulang suara juga dapat ditempuh melalui seolah menambah pertemanan maupun persahabatan, karena hal tersebut dapat menambah orang yang memiliki hubungan dekat dengan calon sehingga mereka akan bersimpati dengan kepadanya. Adanya kedekatan hubungan dapat mempengaruhi orang tersebut untuk mengajak temannya memilih calon tersebut. 


\section{Simpulan}

Siasat partai politik berupa siasat manipulative untuk pemenangan calon legislative dan ekcalon eksekutif. Calon legislative dan eksekutif tidak harus kader partai. Budaya kerja kaderisasi partai politik penguasa di Surabaya juga menggunakan siasat manipulatif. Ini diawali proses sosialisasi untuk rekrutmen anggota baru melalui publikasi pada media cetak, elektronik, dan website. Untuk menjadi anggota partai berlaku bagi semua golongan masyarakat tanpa membeda-bedakan latar belakang seseorang. Partai memiliki bidang khusus yang menangani kaderisasi (Badiklat di tingkat pusat, Badiklatda di tingkat daerah dan Badiklatcab di tingkat cabang), sedangkan tingkatan kaderisasi terbagi menjadi tingkat pratama, tingkat madya, dan tingkat utama. Materi yang disampaikan pada tiap tingkatan kaderisasi berkelanjutan dan saling berhubungan jadi setiap kader harus sudah memahami materi yang diberikan pada tingkat pratama untuk bisa menempuh kaderisasi tingkat madya dan seterusnya. Dalam mekanisme pemilihan kader partai yang hendak diusung menjadi calon dalam Pemilihan Anggota Legislatif (DPRD) atau Walikota Kota Surabaya, kewenangan Dewan Pengurus Cabang hanya sebatas mengusulkan nama, sedangkan penentuan calon merupakan keputusannya mutlak dari Dewan Pimpinan Pusat.

Dinamika yang dialami kader PDIP antara lain: 1). Adanya perebutan kekuasaan internal partai berupa persaingan, pembentukan kubu-kubu berdasarkan calon yang diusungnya, dan banyaknya penjegalan oleh lawan politik; 2). Kurangnya pengetahuan ilmu politik seperti kader yang mengalami kesulitan dalam memahami ilmu politik; dan 3). Harapan masyarakat yang terlampau tinggi terhadap kader terpilih.

Siasat manipulatif kader partai politik untuk pemenangan saat mengikuti Pemilihan Anggota Legislatif (DPRD) dan Eksekutif Pemilihan Walikota Kota Surabaya terbagi menjadi tujuh siasat manipulatif, antara lain: Penentuan calon yang diusung dalam pemilihan tergantung dari keputusan DPP partai meskipun calon bukan kader partai dan bukan anggota partai, kegiatan sosial menjelang pemilu berupa penyelenggaraan kegiatan sosial kepada masyarakat bertujuan mendapat perhatian dari masyarakat, memanfaatkan jabatan publik untuk bekerja secara optimal mengupayakan pelayanan masyarakat dalam upaya meningkatkan elektabilitas, membangun citra partai seolah baik, untuk mengangkat citra kader, melibatkan orang lain untuk mendulang perolehan suara.

\section{Daftar Pustaka}

Ainurhidayat (2012) Organisasi Sosial Sebagai Unsur Budaya. Di akses 3 Desember 2019, dari https://ainurhidayat.blogspot.com/2012/05/organsiasi-sosial-sebagai-unsurbudaya.html?m=1.

Bailey. F. G. (1971). Gifts and Poison: The Politics of Reputation. New York: Echocken.

Budiardjo. M. (2008) Dasar-Dasar Ilmu Politik. Jakarta: Gramedia Pustaka.

Cholisin (2004) Pendidikan Kewarganegaraan (Civic Education). Yogyakarta: Fakultas Ilmu Sosial dan Ekonomi UNY.

Harjanto, N. (2011) Politik Kekerabatan dan Institusionalisasi Partai Politik di Indonesia. Jurnal Analisis CSIS, 40 (2): 138-159. 
Koentjaraningrat (2002) Pengantar Ilmu Antropologi. Jakarta: PT. Rineka Cipta.

Maran, R. R. (2007) Pengantar Sosiologi Politik. Edisi Kedua. Jakarta: Rineka Cipta.

Panantang, G. V. (2012) Model Rekrutmen dan Kaderisasi Partai Demokrasi Indonesia Perjuangan DPC PDIP Kota Kediri. Jurnal Pendidikan Kewarganegaraan, 1 (1): 2-17.

Pattiasina, H. Y. (2015) Strategi Komunikasi Politik PDI Perjuangan Kabupaten Maluku Tengah Pada Pemilu 2014. Jurnal Penelitian Komunikasi dan Opini Publik 19 (1): $17-$ 27.

Permana, A. S. (2015) Pola Kaderisasi Kepemimpinan Partai Politik (Studi Terhadap Dewan Pimpinan Cabang (DPC) Partai Demokrasi Indonesia Perjuangan (PDI-Perjuangan) Kabupaten Nganjuk). Kajian Moral dan Kewarganegaraan 2 (3): 754-769.

Robbins, Stephen P. dan Judge, Timothy A. (2008) Perilaku Organisasi Edisi ke-12, Jakarta: Salemba Empat.

Winataputra, S. Udin. \& Budimansyah, Dasim (2007) Civic Education, Konteks, Landasan, Bahan Ajar dan Kultur Kelas. Bandung: UPI. 